\title{
Consolidating the University Career Service System in Taiwan
}

\author{
Hsuan-Fu $\mathrm{Ho}^{1} \&$ Tien-Ling $\mathrm{Hu}^{1}$ \\ ${ }^{1}$ National Chiayi University, Chiayi, Taiwan \\ Correspondence: Hsuan-Fu Ho, Graduate Institute of Educational administration and Policy Development, \\ National Chiayi University, No.85, Wunlong Village, Minsyong Township, Chiayi County 621, Taiwan (R.O.C). \\ Tel: 886-5-226-3411\#2421 2423. E-mail: hfho@mail.ncyu.edu.tw
}

$\begin{array}{lr}\text { Received: June 21,2017 } & \text { Accepted: July 30, } 2017 \quad \text { Online Published: October 28, } 2017 \\ \text { doi:10.5539/ies.v10n11p148 } & \text { URL: https://doi.org/10.5539/ies.v10n11p148 }\end{array}$

\begin{abstract}
The university graduate unemployment rate reached a record high of $6 \%$ in 2009 in Taiwan; paradoxically, business managers complained that they could not find enough qualified employees. The mismatch between knowledge taught in universities and the requests of the job market has been criticized as the main reason for the escalation of the university graduate unemployment rate. To alleviate the aforementioned crisis, this research endeavored to identify the major career services that should be provided by universities, calculate the relative importance of each career service, and determine which department should be responsible for what career services. The analytic hierarchy process (AHP) was adopted as the major research method, and a self-developed questionnaire was administered to 30 university faculty and 50 students. The results indicated that real work place practice and internships were rated as the most important career service that should be carried out by universities immediately. Moreover, the career center and academic department office are the most important offices in accomplishing the career services.
\end{abstract}

Keywords: employability, employment rate, job market, higher education

\section{Introduction}

University graduates are often expected to have a good job after their graduation, but this is no longer true in Taiwan. The university graduate unemployment rate reached a record high of 6.02 in 2009 in Taiwan, and the situation has gotten worse almost every year thereafter. On the other hand, business executives have lamented that it is very difficult for them to find enough qualified employees because most of the university graduates do not possess competences to accomplish assignments in the workplace. This mismatch between competences requested by the job market and competences taught in the universities has aroused enormous concerns among government officials, educators, and the general public. Accordingly, Taiwan's government mandated that all universities should strengthen their graduate career services as well as develop a curriculum more responsive to job market demands.

This research thus aims to identify the major career services universities should accomplish to assist their students in developing a good career after graduation and determine which university office should be responsible for specific career services. The research questions are as follows:

(1) What are the major career services that should be provided by universities?

(2) What is the relative importance of each university career service?

(3) Which administrative office should be responsible for specific career services?

\subsection{Enhancing University Graduate Employment Rate via Career Services}

The emerging "knowledge economy" or "knowledge society" has increasingly forced governments in the world to ensure the adequate provision of high quality manpower if the aim is to survive the new global market competitions (Chen, 2012). Since universities are often centers for high quality manpower cultivation in a country, enhancing the university graduate employability has become one of the most crucial issues facing all governments in the world (Holmes, 2013). However, the employment rate of university graduates has decreased dramatically in many countries due to over-education or mismatches between university instruction and job market requests. Accordingly, the enhancement of the university graduate employment rate has been mandated by most governments in the world (Barone \& Ortiz, 2011). 
Although many approaches might lead to the enhancement of the graduate employment rate, the most effective approach involves strengthening the university career service system (Clark, 2012; Majewsky, 2013). As the university unemployment rate has risen dramatically in many countries in recent years, more and more students are seeking assistance of the career centers in the universities. Rowley and Purcell (2001) researched university students in the United Kingdom and found that the majority of participants utilized the career center at least once. The authors concluded that not only will more students have to rely on university career services to find jobs in the future, but an increasing number of employers are also relying on university career centers to find high quality job applicants. Despite the importance of the career services in the higher educational system, there is very scarce research or guidance on ensuring the quality of the university career services, which in turn leads to inefficient performance of career services in many universities (Simon, 2013).

\subsection{Approaches of University Career Services}

Although most of the universities in the world have recognized the importance of the career service system, the implementation of such services varies widely among different universities. Simon (2013) argued that a university career service system should include assisting students to acquire competences requested by employers, matching the university teachings to the job market requests, assisting students to possess adequate job application skills, and building strong relationships with local, regional, and national employers to broaden graduates' career opportunities.

Clark (2012) further stressed that providing career information is crucial to the enhancement of the graduate employment rate. It is not enough to merely provide students with career information, such as career trends or job opportunities; universities must train students to become career researchers and assist them in recognizing the crucial competences requested by the job market themselves. In addition, many scholars have emphasized the link between university curriculum and the competence requested by the job market. Myrick and Carrow (1987) argued that, although knowledge exploration and creation are major responsibilities of universities, they should also stress providing high quality manpower to assist with economic development. Therefore, the curriculum developed in universities should include some interactions with society.

Gore (2005) further illustrated that universities may adequately hire professors or instructors who are professionals in the workplace so that students will have more opportunities to get first-hand career information and will have more chance to obtain hands-on experiences. Sagen, Dallam, and Laverty (2000) highlighted that hands-on experience is very important in cultivating students' professional knowledge and skills, and universities should try their best to arrange more workplace activities for students.

Rider, Oeder, Nguyen, and Rodis (2014) argued that assisting students to write good resumes and learn interview skills will effectively enhance the university graduate employment rate. They asserted that, although career service centers in many universities often ignore the importance of interview skills, the research results indicated that graduates who learn better interview skills often have better chances to gain a good job. Furthermore, Gore (2005) recommended that one of the most important tasks of the university career service system is to build strong relationships with the business world.

This relationship might expand university graduates' opportunities to get into a company and, at the same time, companies might have better opportunities to recruit high quality university graduates.

\section{Method}

This research adopted analytic hierarchy process (AHP) as the main measurement method. AHP is a method developed mainly to solve complex problems (Saaty, 1990). By breaking down a large and complex problem into subsequent smaller problems, AHP allows researchers to have a deeper understanding of each determinant in the structure. It also provides researchers with a logical organization of the determinants, so the researcher can have a better understanding of the whole policy making or decision process. AHP is extremely powerful in figuring out the relative weights of each determinant as well as selecting the most adequate policy alternatives. Therefore, we decided to adopt AHP as the major measurement method in this research.

The first step of performing an AHP analysis is to develop the AHP research structure, which is illustrated in Figure 1. The first level is the main goal of this research-enhancing the graduate employment rate. The second level contains the four dimensions of services that are necessary to carrying out the main goal: career information analysis, professional competence cultivation, job hunting training, and career opportunity broadening. Finally, each of the research dimensions was composed by two career services. 


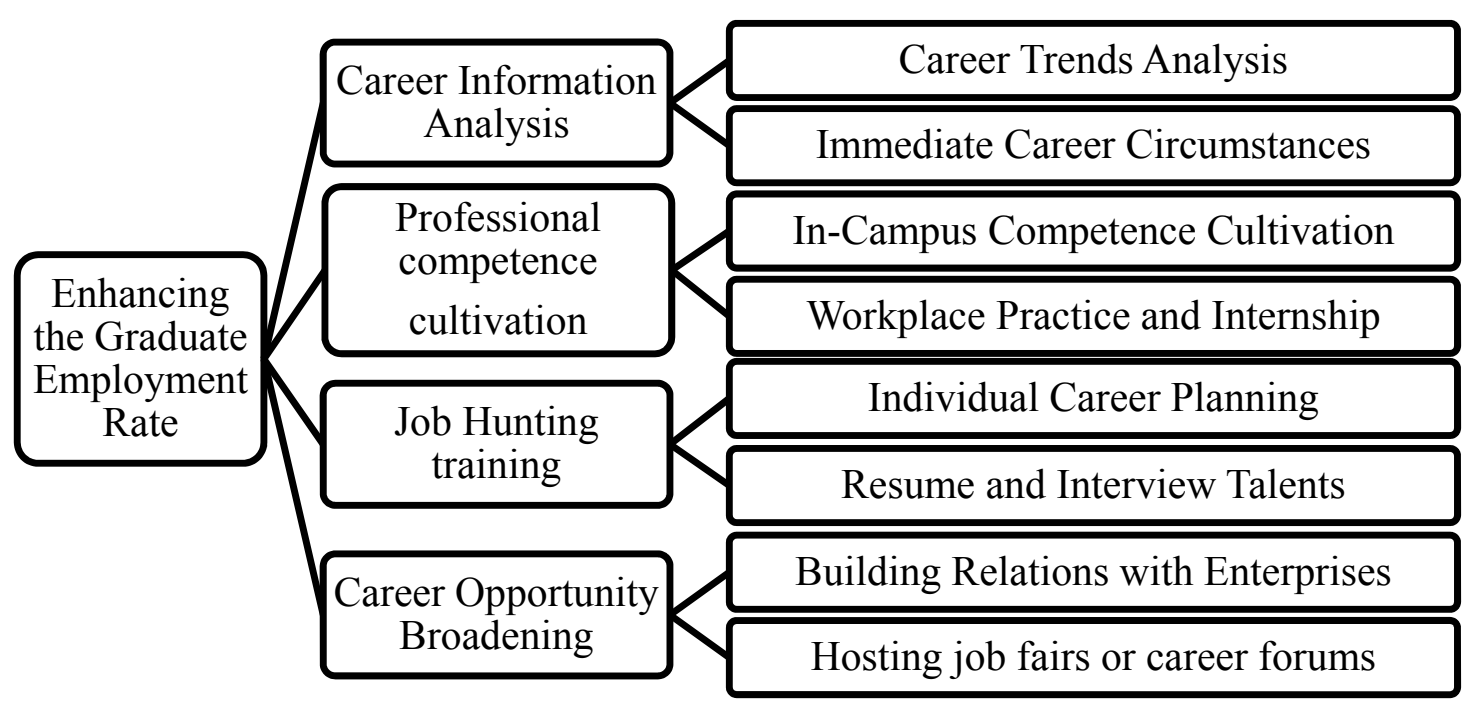

Figure 1. AHP structure

A self-developed questionnaire entitled "Survey of Career Services for Higher Educational Institutions" was employed as the major instrument for information accumulation. It was divided into three parts. Part one was utilized for accumulating participants' demographic information. Part two contains 10 AHP pair-wise questions to determine the relative importance of each university career service. Part three is a contingency table with eight graduate employment tasks in the column and seven responsible university offices in the row; participants were asked to rate the strength of relations between each task and each office. The questionnaire was then reviewed by three scholars who majored in educational administration to ensure that the test items corresponded accurately to the defined research goals. Minor changes were performed according to the opinions of the experts, and then the final version of the questionnaire was administered to 80 university faculty, staff, and students, of which 74 were returned and valid for the subsequent analyses.

\section{Results}

Table 1. Relative importance of career services

\begin{tabular}{|c|c|c|c|c|}
\hline Dimension & $\begin{array}{c}\text { Weight to } \\
\text { the Main } \\
\text { Goal }\end{array}$ & Tasks & $\begin{array}{c}\text { Weight to } \\
\text { the } \\
\text { Dimens }\end{array}$ & $\begin{array}{c}\text { Weight to } \\
\text { the Main } \\
\text { Goal }\end{array}$ \\
\hline \multirow{2}{*}{ Career Information Analysis } & \multirow{2}{*}{.16} & Career Trends Analysis & .45 & .07 \\
\hline & & Immediate Career Circumstances & .55 & .09 \\
\hline \multirow{2}{*}{$\begin{array}{c}\text { Professional Competence } \\
\text { Cultivation }\end{array}$} & \multirow{2}{*}{.45} & On-Campus Competence Cultivation & .31 & .14 \\
\hline & & Workplace Practice and Internship & .69 & .31 \\
\hline \multirow{2}{*}{ Job Hunting Training } & \multirow{2}{*}{.20} & Individual Career Planning & .58 & .12 \\
\hline & & Resume and Interview Talents & .42 & .09 \\
\hline \multirow{2}{*}{ Career Opportunity Broadening } & \multirow{2}{*}{.18} & Building Relations with Enterprises & .78 & .14 \\
\hline & & Hosting Job Fairs or Career Forums & .22 & .04 \\
\hline
\end{tabular}

Table 1 shows the AHP results of this research. We first described the relative weights of each dimension. We also provided information on the relative weights of career services. The research results indicated that professional competence was the most important dimension perceived by the participants, followed by job hunting training, broadening career opportunities, and career information analyses.

Next, we compared the career services under each dimension. The research results indicated that, under the career information analysis dimension, the information for immediate career circumstances was more important than career trends analyses. Under the professional competences dimension, participants tended to rate a higher score for workplace practice and internship than on-campus competence cultivation. Under the job hunting 
training dimension, the research results indicated that the individual career planning career service is more important than resume and interview talents. Finally, under the broadening career opportunities dimension, research participants tended to believe that building relations with enterprises is much more important than hosting job fairs or career forums.

Finally, we generated the relative weights of each career service to the main goal by multiplying the weight of each dimension and the weight of its subsequent career services. The results indicated that the most important career service that universities should carry out is providing students with workplace practice and internship opportunities, which account for $31 \%$ of the total career service responsibility, followed by on-campus cultivation of professional competences $(14 \%)$ and building strong relations with enterprises $(14 \%)$. On the contrary, the hosting job fairs and career forums career service, which was strongly emphasized by almost all universities, was rated as the most useless career service (4\%).

Table 2. Relative importance of career services by different groups

\begin{tabular}{lccc}
\hline Career Services & Academic Faculty & Administrative Staff & Student \\
\hline Career Trends Analysis & .07 & .03 & .09 \\
Immediate Career Circumstances & .09 & .06 & .09 \\
On-Campus Competence Cultivation & .25 & .09 & .12 \\
Workplace Practice and Internship & .27 & .30 & .32 \\
Individual Career Planning & .12 & .14 & .10 \\
Resume and Interview Talents & .04 & .16 & .09 \\
Building Relations with Enterprises & .14 & .17 & .14 \\
Hosting Job Fairs or Career Forums & .03 & .04 & .05 \\
\hline
\end{tabular}

Table 2 indicates that the opinions provided by university faculty members, administrative staff, and students concerning the relative importance of each career services are similar. All three groups provided a very high score for workplace practice and internship opportunities. Moreover, they all gave very low scores to hosting job fairs or career forums, and they also gave lower scores to the service of career trends analyses.

We have to stress that most university leaders and administrators believe that hosting job fairs or career forums is one of the most effective ways to enhance opportunities for students to find a good job. Indeed, every university in Taiwan organizes many job fairs or career forums every year. However, the effectiveness of the job fairs is not appreciated by university faculty, staff, or students. One possible reasons for this is that many prominent companies are willing to attend career forums in only a few prominent universities; therefore, most career forums hosted in universities cannot attract companies that students and teachers appreciate, leading students and teachers in Taiwan to believe that participating in job fairs is a waste of time.

Furthermore, the administrative staff provided a higher score to the resume writing and interview talents cultivation service than their academic faculty and student counterparts. In Taiwan, administrative staff often have to deal with resumes and interviews more than school members in other groups; therefore, they tend to believe that the service related to resume and interviews is very important. Moreover, academic faculty gave a very high score to on-campus professional competence cultivation whereas administrative staff and students tended to rate this service lower. The possible reasons for this research result are that the main duty and value of a professor is to cultivate students' useful knowledge and skills. Consequently, they tend to provide a higher score on professional knowledge cultivation.

Table 3. Effective degree of administrative offices by employment tasks

\begin{tabular}{lccccccc}
\hline & $\begin{array}{c}\text { President's } \\
\text { Office }\end{array}$ & $\begin{array}{c}\text { Career } \\
\text { Center }\end{array}$ & $\begin{array}{c}\text { R\&D } \\
\text { Office }\end{array}$ & $\begin{array}{c}\text { Student } \\
\text { Affairs } \\
\text { Office }\end{array}$ & $\begin{array}{c}\text { Instruct. } \\
\text { Office }\end{array}$ & $\begin{array}{c}\text { College } \\
\text { Office }\end{array}$ & $\begin{array}{c}\text { Depart. } \\
\text { Office }\end{array}$ \\
\hline $\begin{array}{l}\text { Career Trends \& Strengths } \\
\text { Analysis }\end{array}$ & 1.57 & 4.54 & 3.07 & 2.77 & 2.69 & 3.38 & 3.70 \\
$\begin{array}{l}\text { Current Career Situation } \\
\text { Competence Cultivation }\end{array}$ & 1.54 & 4.64 & 2.92 & 2.80 & 2.68 & 3.39 & 3.37 \\
$\begin{array}{l}\text { Real Workplace Practices } \\
\text { and intern }\end{array}$ & 1.38 & 3.16 & 2.76 & 2.43 & 2.77 & 3.93 & 4.61 \\
\hline
\end{tabular}




\begin{tabular}{|c|c|c|c|c|c|c|c|}
\hline Individual Career Planning & 1.50 & 4.65 & 2.55 & 2.76 & 2.74 & 3.41 & 3.70 \\
\hline Resume Interview Training & 1.51 & 4.53 & 2.32 & 2.70 & 2.85 & 3.18 & 3.64 \\
\hline $\begin{array}{l}\text { Building Relations with } \\
\text { Enterprises }\end{array}$ & 2.61 & 3.50 & 3.50 & 2.64 & 2.55 & 3.38 & 3.61 \\
\hline $\begin{array}{l}\text { Holding Job Fairs } \\
\text { or Career Forums }\end{array}$ & 2.18 & 4.43 & 2.99 & 3.04 & 2.64 & 3.16 & 2.84 \\
\hline
\end{tabular}

As Table 3 shows, the career center in universities was the most important administrative office in carrying out almost all student career services. As perceived by the participants, the university career center gained the highest scores in providing information on career trends and immediate workplace circumstances, assisting students in developing their individual career plans and improving students' resume writing and interview skills, and hosting job fairs or career forums. The academic department office also plays a very important role in assisting students to find a good job in the future, and it gained the highest scores in teaching students professional knowledge and skills, providing students with workplace practice and internship opportunities, and building relations with enterprises. The academic college office and office of R\&D also earned higher scores in competence cultivation, workplace practice and internship opportunities, and building relations with enterprises. On the contrary, the president's office, the office of student affairs, and the office of instruction are deemed to be not as important in carrying out career services.

Table 4. Effective degree of administrative offices by employment tasks perceived by different groups

\begin{tabular}{|c|c|c|c|c|c|c|c|c|}
\hline Career Service & Group & $\begin{array}{l}\text { President's } \\
\text { Office }\end{array}$ & $\begin{array}{l}\text { Career } \\
\text { Center }\end{array}$ & $\begin{array}{l}\text { R\&D } \\
\text { Office }\end{array}$ & $\begin{array}{c}\text { Student } \\
\text { Affairs } \\
\text { Office }\end{array}$ & $\begin{array}{l}\text { Instruct. } \\
\text { Office }\end{array}$ & $\begin{array}{c}\text { College } \\
\text { Office }\end{array}$ & $\begin{array}{l}\text { Depart } \\
\text { Office }\end{array}$ \\
\hline \multirow{3}{*}{$\begin{array}{l}\text { Career Trends \& Strengths } \\
\text { Analysis }\end{array}$} & Faculty & 1.00 & 4.88 & 2.88 & 2.18 & 1.88 & 2.35 & 2.82 \\
\hline & Staff & 1.78 & 4.22 & 3.56 & 2.78 & 2.67 & 3.22 & 3.78 \\
\hline & Student & 1.76 & 4.54 & 3.04 & 3.07 & 3.07 & 3.89 & 4.13 \\
\hline \multirow{3}{*}{ Current Career Situation } & Faculty & 1.06 & 4.94 & 2.53 & 2.00 & 1.88 & 2.47 & 3.06 \\
\hline & Staff & 1.89 & 4.33 & 3.22 & 2.78 & 2.56 & 3.22 & 4.00 \\
\hline & Student & 1.67 & 4.57 & 3.09 & 3.17 & 3.07 & 3.87 & 4.11 \\
\hline \multirow{3}{*}{ Competence Cultivation } & Faculty & 1.00 & 2.35 & 1.88 & 1.82 & 3.35 & 3.65 & 4.41 \\
\hline & Staff & 1.22 & 3.00 & 2.33 & 2.44 & 2.56 & 3.89 & 4.44 \\
\hline & Student & 1.57 & 3.59 & 3.24 & 2.72 & 2.67 & 4.17 & 4.70 \\
\hline \multirow{3}{*}{$\begin{array}{l}\text { Real Workplace Practices and } \\
\text { Intern }\end{array}$} & Faculty & 1.12 & 3.29 & 3.06 & 2.12 & 2.53 & 3.29 & 3.94 \\
\hline & Staff & 1.56 & 4.11 & 3.56 & 2.11 & 2.44 & 3.56 & 3.89 \\
\hline & Student & 1.96 & 3.85 & 3.11 & 3.07 & 2.93 & 3.98 & 4.39 \\
\hline \multirow{3}{*}{ Individual Career Planning } & Faculty & 1.12 & 4.76 & 1.94 & 2.18 & 1.88 & 2.53 & 2.88 \\
\hline & Staff & 1.67 & 4.33 & 2.56 & 2.44 & 2.89 & 3.44 & 3.44 \\
\hline & Student & 1.63 & 4.65 & 2.85 & 3.11 & 3.11 & 3.83 & 4.17 \\
\hline \multirow{3}{*}{ Resume Interview Training } & Faculty & 1.06 & 4.71 & 1.88 & 2.00 & 2.35 & 2.24 & 3.06 \\
\hline & Staff & 1.44 & 4.11 & 2.00 & 2.78 & 3.00 & 3.11 & 3.44 \\
\hline & Student & 1.72 & 4.52 & 2.61 & 3.02 & 3.09 & 3.63 & 4.00 \\
\hline \multirow{3}{*}{$\begin{array}{l}\text { Building Rela } \\
\text { Enterprises }\end{array}$} & Faculty & 2.18 & 3.71 & 3.71 & 1.76 & 1.76 & 2.59 & 3.12 \\
\hline & Staff & 2.56 & 3.67 & 4.33 & 2.33 & 2.33 & 3.11 & 3.89 \\
\hline & Student & 2.85 & 3.50 & 3.17 & 3.09 & 2.96 & 3.83 & 3.85 \\
\hline \multirow{3}{*}{$\begin{array}{l}\text { Holding Job Fairs or Career } \\
\text { Forums }\end{array}$} & Faculty & 1.59 & 4.53 & 3.06 & 2.53 & 1.76 & 2.59 & 2.71 \\
\hline & Staff & 1.89 & 4.56 & 3.67 & 2.89 & 2.22 & 3.22 & 2.67 \\
\hline & Student & 2.41 & 4.43 & 2.91 & 3.35 & 3.11 & 3.46 & 3.00 \\
\hline
\end{tabular}

Finally, we examined the variation among faculty, staff, and students in terms of their opinions toward the importance of each career services. Table 4 indicates that the three groups of school members hold very similar opinions toward the importance of the university career center and the academic department offices in carrying out career services. Moreover, all three groups indicated that the president's office, the office of student affairs, and the office of instruction do not have much to do in carrying out the university career services. 
It is also interesting to recognize that students rated a higher score than faculty and staff members for the academic college office in carrying out all of the career services identified in this research. A possible reason for this result is that the academic college offices serve as the main institute in most universities for curriculum design and implementation of university policies; therefore, students tend to have more interactions with the members serving in the university college offices than with those in the president's office or office of instruction, which in turn leads students to believe that academic college offices should play an important role in carrying out career services.

\section{Conclusion and Recommendations}

University students in Taiwan have difficulty finding an adequate job after graduation; at the same time, many business managers complain a great deal that they cannot recruit enough employees who possess the basic competences required in the job market. As this mismatch between the job market and universities has significantly hurt the economic development in Taiwan, the government has mandated that universities should put more emphasis on improving their career services. Thus, this research endeavored to identify the major career services that should be offered by universities and determine which university office should be responsible for specific career services.

The research results showed that workplace practices and internship opportunities as well as on-campus professional competence cultivation are the most important career services that should be offered by universities to enhance the graduate employment rate. Meanwhile, although universities in Taiwan host a lot of job fairs or career forums every year, the effectiveness of this career service was not identified by all three groups of research participants. This finding is very important for Taiwan to improve its university career service system. Those universities that cannot attract ideal companies to participate in their job forums may have to reduce the number of job fairs or career forums; rather, they should invest more in career services that will make real contributions in enhancing graduate employability, such as providing more workplace practice and internship opportunities, cultivating professional knowledge and skills requested by the job market, and strengthening relationships with prominent enterprises.

It is also valuable to realize that the university career center is an important facility for carrying out almost all career services to enhance the graduate employment rate. In Taiwan, many universities do not recognize the importance of the career center, and many universities even make the university career center a subsidiary institute under the rule of the office of student affairs or the office of $R \& D$, which is not adequate if the aim is to answer the mandates by Taiwan's government of effectively enhancing the graduate employment rate.

The academic department office also plays a crucial role in carrying out the career services in the universities, especially in cultivating professional knowledge and skills necessary for the career success after graduation. Regrettably, the universities in Taiwan have long been criticized as an ivory tower that is often missing the link with external society, which in turn leads to the mismatch between university teaching and job market requests. As the academic department office is the main institute in designing the curriculum, it is crucial to strengthen the link between professors and the business world, so that the knowledge and skills taught in the universities may better answer the requests from the job market.

Finally, the research results indicated that, although university faculty, staff, and students hold very similar patterns concerning the relative importance of each career service and the function of university offices, faculty members tend to stress more on cultivating professional competences, while administrative staff put more importance on resume writing and interview training. Moreover, students emphasize much more than their faculty and staff counterparts on the function of the academic college offices in carrying out the career services. Although we offer some possible reasons for these phenomena, an in-depth qualitative research in the future is strongly recommended to further explore the real reasons for the aforementioned research results.

\section{References}

Barone, C., \& Ortiz, L. (2011). Over education among European university graduates: A comparative analysis of its incidence and the importance of higher education differentiation. Higher Education, 61(3), 325-337. https://doi.org/10.1007/s10734-010-9380-0

Chen, S. Y. (2012). Contributing knowledge and knowledge workers: the role of Chinese universities in the knowledge economy. London Review of Education, 10(1), 101-112. https://doi.org/10.1080/14748460.2012.659062

Clark, W. (2012). It's about more than getting a job. Adults Learning, 23(4), 45-47.

Gore, T. (2005). Extending employability or solving employers' recruitment problems? Demand-led approaches 
as an instrument of labour market policy. Urban Studies, 42(2), 341-353. https://doi.org/10.1080/0042098042000316182

Holmes, L. (2013). Competing perspectives on graduate employability: possession, position or process. Studies in Higher Education, 38(4), 538-554. https://doi.org/10.1080/03075079.2011.587140

Majewsky, E. (2013). Higher education reform: Matching education to labour market needs. European View, 12 , $179-188$.

Myrick, R. D., \& Carrow, P. A. (1987). Teacher involvement in career education and advisement: Ready or not? Journal of Advanced Nursing, 15(11), 1281-1288.

Rider, S., Oeder, J. L., Nguyen, T. T., \& Rodis, J. L. (2014). A collaborative approach to residency preparation programming for pharmacy students. American Journal of Health-System Pharmacy, 71(11), 950-955. https://doi.org/10.2146/ajhp130544

Rowley, G., \& Purcell, K. (2001). Up to the job? Graduates' perceptions of the UK Higher Education Careers Service. Higher Education Quarterly, 55(4), 416-435. https://doi.org/10.1111/1468-2273.00196

Saaty, T. L. (1990). Decision making for leaders: The analytic hierarchy process for decisions in a complex world. Pittsburgh, PA: RWS Publications.

Sagen, H. B., Dallam, J. W., \& Laverty, J. R. (2000). Effects of career preparation experiences on the initial employment success of college graduates. Research in Higher Education, 41(6), 753-767. https://doi.org/10.1023/A:1007072705601

Simon, A. (2013). Quality assurance in university guidance services. British Journal of Guidance and Counseling, 42(2), 181-198. https://doi.org/10.1080/03069885.2013.869789

\section{Copyrights}

Copyright for this article is retained by the author(s), with first publication rights granted to the journal.

This is an open-access article distributed under the terms and conditions of the Creative Commons Attribution license (http://creativecommons.org/licenses/by/4.0/). 